\title{
The non-genomic effects of endocrine-disrupting chemicals on mammalian sperm
}

\author{
R S Tavares ${ }^{1,+}$, S Escada-Rebelo ${ }^{1}$, M Correia ${ }^{1,2}$, P C Mota ${ }^{1,3}$ and J Ramalho-Santos ${ }^{1,4}$ \\ ${ }^{1}$ Biology of Reproduction and Stem Cell Group, ${ }^{2}$ PhD Programme in Experimental Biology and Biomedicine, \\ CNC-Center for Neuroscience and Cell Biology, University of Coimbra, Rua Larga, Faculty of Medicine, Pólo I, \\ 1st floor, 3004-504 Coimbra; ${ }^{3}$ Institute for Interdisciplinary Research (IIIUC), University of Coimbra, Casa Costa \\ Alemão - Pólo II, Rua Dom Francisco de Lemos 3030-789 Coimbra and ${ }^{4}$ Department of Life Sciences, \\ University of Coimbra, Calçada Martim de Freitas, 3000-456 Coimbra, Portugal
}

Correspondence should be addressed to J Ramalho-Santos; Email: jramalho@ci.uc.pt

${ }^{\dagger} \mathrm{R} S$ Tavares is now at Neuroscience and Cellular Signaling Group, Health Sciences Department, Institute of Biomedicine (iBiMED), University of Aveiro, 3810-193 Aveiro, Portugal

\begin{abstract}
Exposure to toxicants present in the environment, especially the so-called endocrine-disrupting chemicals (EDCs), has been associated with decreased sperm quality and increased anomalies in male reproductive organs over the past decades. Both human and animal populations are continuously exposed to ubiquitous synthetic and natural-occurring EDCs through diet, dermal contact and/or inhalation, therefore potentially compromising male reproductive health. Although the effects of EDC are likely induced via multiple genomic-based pathways, their non-genomic effects may also be relevant. Furthermore, spermatozoa are transcriptionally inactive cells that can come in direct contact with EDCs in reproductive fluids and secretions and are therefore a good model to address non-genomic effects. This review thus focuses on the non-genomic effects of several important EDCs relevant to mammalian exposure. Notably, EDCs were found to interfere with pre-existing pathways inducing a panoply of deleterious effects to sperm function that included altered intracellular $\mathrm{Ca}^{2+}$ oscillations, induction of oxidative stress, mitochondrial dysfunction, increased DNA damage and decreased sperm motility and viability, among others, potentially jeopardizing male fertility. Although many studies have used non-environmentally relevant concentrations of only one compound for mechanistic studies, it is important to remember that mammals are not exposed to one, but rather to a multitude of environmental EDCs, and synergistic effects may occur. Furthermore, some effects have been detected with single compounds at environmentally relevant concentrations.
\end{abstract}

Reproduction (2016) 151 R1-R13

\section{Introduction}

In 1992, a landmark report revealed a decrease of sperm concentration from an average of $113-66 \times 10^{6}$ of spermatozoa $/ \mathrm{ml}$ of semen over a 50 -year period in men with no history of infertility (Carlsen et al. 1992). Furthermore, a reduction in mean semen volume was also described, thereby indicating a decrease in total sperm count (Carlsen et al. 1992). Subsequently, other studies have reported diminished sperm quality determined by the reduction in concentration, motility and/or normal morphology (Auger et al. 1995, Toppari et al. 1996) accompanied by an increasing trend in testicular cancer and abnormalities in male reproductive organs, such as criptorchidism and hypospadias (Toppari et al. 1996). Although this is a controversial subject and several factors have been suggested to affect male reproductive health and fertility worldwide, both in humans and wildlife, it has been extensively argued that certain toxicants present in the environment, mainly substances that possess (anti)estrogenic- or antiandrogenic-like activities dubbed endocrine-disrupting chemicals (EDCs), may play an important role in such reproductive dysfunction.

Environmental EDCs can affect the action of endogenous hormones and deregulate hormonal balance through multiple mechanisms. Some of these substances can mimic reproductive hormones such as testosterone and estradiol $\left(E_{2}\right)$ and interfere with their synthesis, binding and/or action, therefore potentially affecting male reproductive capacity (Phillips \& Tanphaichitr 2008). Although structural similarities are often noted between EDC and endogenous hormones, this does not constitute a rule. In fact, EDCs are a highly heterogeneous group of compounds that include synthetic substances originated from industrial processes such as pesticides, polychlorinated dibenzo-p-dioxins (PCDDs), polychlorinated 
biphenyls (PCBs), polycyclic aromatic hydrocarbons (PAHs), phthalates, and bisphenol $\mathrm{A}$ as well as natural compounds with hormonal activity, mainly phytoestrogens and mycotoxins. In general, EDCs are potentially serious hazards to the broad human and animal populations given their ubiquitous distribution and persistency in the environment. Even though many have been banned or restricted in most countries as agreed in the Stockholm Convention regarding persistent organic pollutants (POPs; e.g., PCDDs, PCBs, several pesticides, and PAHs), EDCs may be very resistant to degradation and be present via air, soil, water and food contamination (e.g. fish, meat, and milk; Hauser et al. 2002). Furthermore, it is important to mention that due to their lipophilic nature, POPs bioaccumulate in the food chain. In fact, as these substances can be stored preferentially in body fat for long time periods, top food chain species are the most susceptible, because in addition to being directly exposed, they feed on organisms already with accumulations of these compounds in their body tissues (Guillette 1994).

Besides being detected in urine (Jonsson et al. 2005, Xia et al. 2009, Jurewicz et al. 2013), breast milk (Chikuni et al. 1991, Mocarelli et al. 2011), and blood serum (Younglai et al. 2002, Mocarelli et al. 2008), important amounts of EDCs have also been found in secretions of the female reproductive tract, cervical mucus and follicular and seminal fluids (Tsutsumi et al. 1998, Younglai et al. 2002, Drbohlav et al. 2005). This is particularly relevant as spermatozoa steep in these reproductive fluids/secretions on their journey toward the oocyte and are therefore in direct contact with such toxicants, an important route of exposure that should not be neglected. Importantly, mounting evidence has shown that these man-made or naturally occurring compounds may act through multiple pathways. Besides modulating gene transcription, they may equally promote non-genomic actions that may ultimately compromise sperm fertilizing ability and jeopardize male fertility. To this extent, spermatozoa are excellent models for the analysis of such putative effects given their transcriptional inactivity, a consequence of the highly condensed nature of sperm chromatin due to histone replacement by protamines. With this in mind, the present review mainly focuses on the direct effects of EDCs (Table 1) and explores their mechanisms of action in mature mammalian spermatozoa.

\section{Man-made chemicals: sources of exposure and effects on spermatozoa}

\section{Pesticides}

With the purpose of preventing, abolishing or controlling any pest, pesticides represent an extensive and diverse group of substances that have been shown to possess antiandrogenic and/or estrogenic activity in vivo and in vitro (Lemaire et al. 2004, Sengupta \& Banerjee 2014). The use of synthetic pesticides has increased worldwide over the last decades, mostly as a way of obtaining higher crop yields, although their use in home formulations are also a reality (Sengupta \& Banerjee 2014). With more than 140000 tons used annually only in the European Union (Bjørling-Poulsen et al. 2008), it is safe to assume that their ubiquitous presence in the environment may pose a risk to human and animal health.

Based on their chemical structure, pesticides can be divided into several subclasses, with organochlorines, organophosphates and pirethroids being the most commonly known (Sengupta \& Banerjee 2014). Although with some exceptions probably attributed to the dissimilar concentrations detected in body fluids, exposure to these compounds detected in urine, seminal or blood serum samples have been associated with poor standard sperm parameters (Sengupta \& Banerjee 2014).

Sperm motility in particular is of paramount importance for a given spermatozoon to reach and penetrate the oocyte and without which it does not have any fertilizing potential. In vitro studies have clearly shown that, whether determined by a computer-assisted sperm analyzer (CASA) system or simple phase-contrast microscopy, the pirethroids deltamethrin, cypermethrin and fenvalerate, as well as the organophosphates dimethoate, malathion and diazinon and the herbicides alachlor, bendiocarb, fenoxaprop-ethyl, and atrazine, can significantly reduce such parameter in humans, rodents, rabbit and boar (Table 1; Betancourt et al. 2006, Grizard et al. 2007, Abdallah et al. 2010, 2012, Yuan et al. 2010, Krockova et al. 2012) followed by an increase in cell death (Betancourt et al. 2006, Grizard et al. 2007, Abdallah et al. 2010, 2012). In parallel, the functional status of mitochondria, which is well correlated with sperm fertilizing capability (Amaral et al. 2013) and widely characterized by the determination of the mitochondrial membrane potential (MMP), is also affected by EDCs (Table 1). In fact, the pesticide alachlor was found to depolarize human sperm mitochondria prior to related damage on sperm motility, leading the authors to suggest that the harmful effects may be correlated with mitochondrial dysfunction (Grizard et al. 2007). Additionally, a decrease in sperm antioxidant scavenging defenses and/or an increase in the production of reactive oxygen species (ROS) levels have been detected in human and rat spermatozoa after exposure to deltamethrin, dimethoate and alachlor (Grizard et al. 2007, Abdallah et al. 2010, 2012), suggesting that oxidative stress may play a key role in EDC-mediated effects. Such an imbalance between ROS generation and ROS scavenging may lead to downstream repercussions such as DNA fragmentation (critical for the full expression of the fertility potential), peroxidation of plasma membrane lipids and apoptosis, all of which have already been reported in human spermatozoa exposed in vitro to pirethroids, 
Table 1 Experimental evidence showing the direct effects of EDCs on sperm parameters/features

\begin{tabular}{|c|c|c|c|c|c|}
\hline $\begin{array}{l}\text { Sperm parameter/ } \\
\text { feature }\end{array}$ & EDC & Species & $\begin{array}{l}\text { Concentrations tested } \\
\text { (no. of samples, replicates or experiments) }\end{array}$ & Main outcome & References \\
\hline \multirow[t]{32}{*}{ Motility } & Pesticides & & & & \\
\hline & Alachlor & Human & $0.18,0.37,0.90$, and $1.85 \mathrm{mM}(10)$ & Decreased & Grizard et al. (2007) \\
\hline & $\beta-\mathrm{HCH}$ & & $76.94,384.7$, and $769.4 \mu \mathrm{g} / \mathrm{l}(3)$ & & Pant et al. (2013) \\
\hline & Lindane & & $39.04,195.2$, and $390.4 \mu \mathrm{g} / \mathrm{l}(3)$ & & \\
\hline & $p, p^{\prime}-D D D$ & & $57.49, \mathbf{2 8 7 . 4 5}$, and $\mathbf{5 7 4 . 9} \boldsymbol{\mu g} / \mathbf{l}(3)$ & & \\
\hline & $p, p^{\prime}-D D E$ & & $53.89, \mathbf{2 6 9 . 4 5}$, and $\mathbf{5 3 8 . 9} \boldsymbol{\mu \mathbf { g } / \mathbf { l } ( 3 )}$ & & \\
\hline & & & $10,25, \mathbf{5 0}$, and $\mathbf{1 0 0} \mu \mathbf{M}(5)$ & & Tavares et al. (2015) \\
\hline & Deltamethrin & Rat & $10, \mathbf{5 0}, \mathbf{1 0 0}$, and $\mathbf{2 0 0} \boldsymbol{\mu} \mathbf{M}(8)$ & & Abdallah et al. (2010) \\
\hline & Dimethoate & & $\mathbf{5 0}, \mathbf{1 0 0}$, and $200 \boldsymbol{\mu M}(10)$ & & Abdallah et al. (2012) \\
\hline & Permethrin & & 1, 4, 16, and $\mathbf{6 4} \boldsymbol{\mu} \mathbf{M}(10)$ & & Yuan et al. (2010) \\
\hline & Cypermethrin & & $1,4,16$, and $64 \mu \mathrm{M}(10)$ & & \\
\hline & $\begin{array}{l}\text { Atrazine } \\
\text { Fenoxaprop- } \\
\text { ethyl }\end{array}$ & Boar & 50,100 , and $500 \mu \mathrm{M}$ & & Betancourt et al. (2006) \\
\hline & Diazinon & & $\mathbf{5 0}, 100$, and $\mathbf{5 0 0} \boldsymbol{\mu} \mathbf{M}$ & & \\
\hline & Malathion & & 50,100 , and $500 \mu \mathrm{M}$ & & \\
\hline & Bendiocarb & Rabbit & $\begin{array}{l}0.054,0.107,0.161,0.214 \text {, and } \\
0.268 \mathrm{mg} / \mathbf{m l}(5)\end{array}$ & & Krockova et al. (2012) \\
\hline & PCBs & & & & \\
\hline & PCB54 & Human & $0.1-10 \mathrm{ng} / \mathrm{ml}$ & & Roediger et al. (1989) \\
\hline & $\begin{array}{l}\text { Aroclor } 1254 \\
\text { PAHs }\end{array}$ & Rat & $\mathbf{1 0}^{-\mathbf{9}}, \mathbf{1 0}^{-\mathbf{8}}$, and $\mathbf{1 0}^{-7} \mathbf{M}(6)$ & & Aly (2013) \\
\hline & $\begin{array}{l}\text { Diesel particle } \\
\text { extract }\end{array}$ & Human & $0.001,0.01$, and $0.1,1 \mu \mathrm{g}$ PAHs $/ \mathrm{ml}$ & & Fredricsson et al. (1993) \\
\hline & Phthalates & & & & \\
\hline & DBP & Human & $0.4, \mathbf{4}$, and $\mathbf{4 0} \mathbf{~ m M}$ & & \\
\hline & DEP & & $0.33, \mathbf{3 3 0}$, and $\mathbf{3 3 0 0} \mu \mathbf{M}$ & & \\
\hline & DMP & & 9,94, and $940 \mu \mathrm{M}$ & & \\
\hline & DOP & & 64 and $640 \mu \mathrm{M}$ & & \\
\hline & DEHP & & $0.8,8$, and $80 \mathrm{mM}$ & & \\
\hline & DBP & & $13.47,67.35$, and $134.7 \mu \mathrm{g} / \mathrm{ml}$ & & Pant et al. (2011) \\
\hline & DEHP & & $5.73,28.65$, and $57.3 \mu \mathrm{g} / \mathrm{ml}$ & & \\
\hline & BPA & & & & \\
\hline & BPA & Mouse & $0.0001,0.01,1$, and $\mathbf{1 0 0} \boldsymbol{\mu} \mathbf{M}(4)$ & & Rahman et al. (2015) \\
\hline & $\begin{array}{l}\text { Mycotoxıns } \\
\text { ZEA }\end{array}$ & Boar & 1251875 and $250 \mathrm{MM}(6)$ & & Tcakmakidis \\
\hline & & & & & et al. (2006) \\
\hline & $\alpha-Z O L$ & & & & \\
\hline \multirow{7}{*}{ Mitochondrial function } & & Horse & $1 \mathrm{pM}-\mathbf{1 0 0} \boldsymbol{\mu M}(5)$ & & Filannino et al. (2011) \\
\hline & $\begin{array}{l}\text { Pesticides } \\
\text { Alachlor }\end{array}$ & Human & $0.18,0.37,0.90$, and $1.85 \mathbf{m M}(10)$ & Decreased & Grizard et al. (2007) \\
\hline & $p, p^{\prime}-D D E$ & & $10, \mathbf{2 5}, \mathbf{5 0}$, and $\mathbf{1 0 0} \boldsymbol{\mu M}(5)$ & & Tavares et al. (2015) \\
\hline & Dioxins & & & & \\
\hline & TCDD & Mouse & 1 and $\mathbf{5} \mathbf{~ n M ~ ( 3 ) ~}$ & & Fisher et al. (2005) \\
\hline & PCBs & & & & \\
\hline & Aroclor 1254 & Rat & $\mathbf{1 0 ^ { - 9 }}, \mathbf{1 0}^{-8}$, and $\mathbf{1 0}^{-7} \mathbf{M}(6)$ & & Aly (2013) \\
\hline \multirow[t]{4}{*}{ Cellular ATP content } & Pesticides & & & & \\
\hline & $\begin{array}{l}\text { p,p'-DDE } \\
\text { PCBs }\end{array}$ & Human & $25, \mathbf{5 0}$, and $\mathbf{1 0 0} \mu \mathbf{M}(4)$ & Decreased & Tavares et al. (2015) \\
\hline & Aroclor 1254 & Rat & $10^{-9}, \mathbf{1 0}^{-8}$, and $\mathbf{1 0}^{-7} \mathbf{M}(6)$ & & Aly (2013) \\
\hline & BPA & Mouse & $0.0001,0.01,1$, and $\mathbf{1 0 0} \boldsymbol{\mu M}$ (4) & & Rahman et al (2015) \\
\hline \multirow[t]{7}{*}{ Oxidative stress } & Pesticides & & & & Naminall el al. (201J) \\
\hline & Alachlor & Human & 0.37 and $\mathbf{1 . 8 5} \mathbf{~ m M ~ ( 1 2 ) ~}$ & Increased & Grizard et al. (2007) \\
\hline & Deltamethrin & Rat & $10,50,100$, and $200 \mu \mathrm{M}(8)$ & & Abdallah et al. (2010) \\
\hline & Dimethoate & & 50,100 , and $200 \mu \mathrm{M}(10)$ & & Abdallah et al. (2012) \\
\hline & PCBs & & & & \\
\hline & $\begin{array}{l}\text { Aroclor } 1254 \\
\text { PAHs }\end{array}$ & Rat & $\mathbf{1 0}^{-9}, \mathbf{1 0}^{-8}$, and $\mathbf{1 0}^{-7} \mathbf{M}(6)$ & & Aly (2013) \\
\hline & $\mathrm{B}[\mathrm{a}] \mathrm{P}$ & Human & $\mathbf{5 0 0} \mu \mathbf{M}(4)$ & & Russo et al. (2006) \\
\hline \multirow[t]{4}{*}{ Lipid peroxidation } & Pesticides & & & & \\
\hline & Deltamethrin & Rat & $10,50,100$, and $200 \mu \mathrm{M}(8)$ & Increased & Abdallah et al. (2010) \\
\hline & $\begin{array}{l}\text { Dimethoate } \\
\text { PCBs }\end{array}$ & & $50, \mathbf{1 0 0}$, and $\mathbf{2 0 0} \mu \mathbf{M}(10)$ & & Abdallah et al. (2012) \\
\hline & Aroclor 1254 & Rat & $\mathbf{1 0}^{-9}, \mathbf{1 0}^{-8}$, and $\mathbf{1 0}^{-7} \mathbf{M}(6)$ & & Aly (2013) \\
\hline Chromatin/ & Pesticides & & & & \\
\hline DNA integrity & Alachlor & Human & 0.37 and 1.85 mM (8) & Decreased & Grizard et al. (2007) \\
\hline
\end{tabular}


Table 1 Continued.

\begin{tabular}{|c|c|c|c|c|c|}
\hline $\begin{array}{l}\text { Sperm parameter/ } \\
\text { feature }\end{array}$ & EDC & Species & $\begin{array}{l}\text { Concentrations tested } \\
\text { (no. of samples, replicates or experiments) }\end{array}$ & Main outcome & References \\
\hline & $\begin{array}{l}\text { Parathion } \\
\text { Paraoxon }\end{array}$ & Mouse & $0.05-\mathbf{0 . 8} \mathbf{~ m M}$ & & Contreras et al. (1999) \\
\hline & PCBs & & & & \\
\hline & $\begin{array}{l}\text { Aroclor } 1254 \\
\text { PAHs }\end{array}$ & Rat & $10^{-9}, \mathbf{1 0}^{-8}$, and $10^{-7} \mathbf{M}(6)$ & & Aly (2013) \\
\hline & $\mathrm{B}[\mathrm{a}] \mathrm{P}$ & Human & $\mathbf{5 0 0} \boldsymbol{\mu M}(4)$ & & Russo et al. (2006) \\
\hline & & & 10 and $25 \mu \mathrm{M}$ (4) & & Sipinen et al. (2010) \\
\hline & BPDE & & $5, \mathbf{2 0}$, and $\mathbf{5 0} \boldsymbol{\mu} \mathbf{M}(4-6)$ & & \\
\hline & Mycotoxins & & & & \\
\hline & ZEA & Boar & 10,20 , and $30 \mu \mathrm{g} / \mathrm{ml}(4)$ & & $\begin{array}{l}\text { Tsakmakidis et al. } \\
\text { (2008) }\end{array}$ \\
\hline & $\alpha-\mathrm{ZOL}$ & & & & \\
\hline & $\begin{array}{l}\alpha-Z A L \\
\alpha-Z O L\end{array}$ & Horse & $25 \times 10^{-6}-250 \mathrm{nM}(3)$ & & Minervini et al. (2010) \\
\hline & $\beta-\overline{Z O L}$ & & & & \\
\hline & ZEA & & & & \\
\hline \multirow{2}{*}{$\begin{array}{l}\text { Chromosomal } \\
\text { anomalies }\end{array}$} & PAHs & & & & \\
\hline & $\mathrm{B}[\mathrm{a}] \mathrm{P}$ & Human & $200 \mu \mathrm{g} / \mathrm{ml}$ & $\begin{array}{l}\text { Increased } \\
\text { structural } \\
\text { aberrations }\end{array}$ & $\begin{array}{l}\text { Watanabe \& Kamiguchi } \\
\text { (2001) }\end{array}$ \\
\hline \multirow[t]{12}{*}{ Capacitation } & Pesticides & & & & \\
\hline & $p, p^{\prime}-D D E$ & Human & 25,50 , and $\mathbf{1 0 0} \boldsymbol{\mu M}(5)$ & Decreased & Tavares et al. (2015) \\
\hline & Atrazine & Boar & 8,20 , and $\mathbf{4 0} \boldsymbol{\mu M}(5)$ & & $\begin{array}{l}\text { Maravilla-Galván } \\
\text { et al. (2009) }\end{array}$ \\
\hline & $\begin{array}{l}\text { Fenoxaprop- } \\
\text { ethyl }\end{array}$ & & 12,30, and $\mathbf{6 0} \boldsymbol{\mu} \mathbf{M}(5)$ & Increased & \\
\hline & $\mathrm{BPA}$ & & & & \\
\hline & BPA & Mouse & $0.0001,0.01,1$, and $\mathbf{1 0 0} \boldsymbol{\mu} \mathbf{M}$ (3) & Decreased & Rahman et al. (2015) \\
\hline & $\mathrm{PAHs}$ & & & & \\
\hline & $\mathrm{B}[\mathrm{a}] \mathrm{P}$ & Human & $12.5,25, \mathbf{5 0}$, and $\mathbf{1 0 0} \boldsymbol{\mu g} / \mathbf{m l}$ & Increased & $\begin{array}{l}\text { Mukhopadhyay et al. } \\
\text { (2010) }\end{array}$ \\
\hline & Phytoestrogens & & & & \\
\hline & Genistein & Human & 1, 10, and $100 \mathrm{nM}(4)$ & & Fraser et al. (2006) \\
\hline & & Boar & $0.001, \mathbf{0 . 0 1}, \mathbf{0 . 1}, \mathbf{1}, \mathbf{1 0}$, and $\mathbf{1 0 0} \mu \mathbf{M}(4)$ & & $\begin{array}{l}\text { Mohamed el et al. } \\
\text { (2011) }\end{array}$ \\
\hline & & Mouse & 1, 10, 100, and $1000 \mathrm{nM}(3-6)$ & & $\begin{array}{l}\text { Adeoya-Osiguwa } \\
\text { et al. (2003) }\end{array}$ \\
\hline \multirow[t]{21}{*}{ Acrosome integrity } & Pesticides & & & & \\
\hline & Lindane & Human & $0.1, \mathbf{1}, \mathbf{5}, \mathbf{1 5}$, and $\mathbf{3 0} \mu \mathrm{M}$ & Increased & $\begin{array}{l}\text { Silvestroni \& Palleschi } \\
\text { (1999) }\end{array}$ \\
\hline & $p, p^{\prime}-D D E$ & & $1, \mathbf{1 0}, \mathbf{2 5}$, and $\mathbf{5 0} \mu \mathrm{M}(6)$ & Decreased & Tavares et al. (2013) \\
\hline & Atrazine & Boar & $8, \mathbf{2 0}$, and $40 \mu \mathrm{M}(5)$ & & $\begin{array}{l}\text { Maravilla-Galván et al. } \\
\text { (2009) }\end{array}$ \\
\hline & $\begin{array}{l}\text { Fenoxaprop- } \\
\text { ethyl }\end{array}$ & & 12,30 , and $60 \mu \mathbf{M}(5)$ & & \\
\hline & Parathion & Mouse & $0.05-\mathbf{0 . 8} \mathbf{~ m M}$ & & Contreras et al. (1999) \\
\hline & Paraoxon & & & & \\
\hline & PCBs & & & & \\
\hline & PCB54 & Human & $0.1-10 \mathrm{ng} / \mathrm{ml}$ & & Roediger et al. (1989) \\
\hline & $\begin{array}{l}\text { Aroclor } 1254 \\
\text { PAHs }\end{array}$ & & $10^{-9}, \mathbf{1 0}^{-8}$, and $10^{-7} \mathbf{M}(6)$ & Increased & Aly (2013) \\
\hline & $\mathrm{B}[\mathrm{a}] \mathrm{P}$ & Human & $12.5, \mathbf{2 5}, \mathbf{5 0}$, and $\mathbf{1 0 0} \boldsymbol{\mu \mathrm { g } / \mathrm { ml }}$ & Decreased & Mukhopadhyay et al. \\
\hline & BPA & & & & \\
\hline & BPA & Mouse & $0.0001,0.01,1$, and $\mathbf{1 0 0} \mu \mathbf{M}$ (3) & & Rahman et al. (2015) \\
\hline & Phytoestrogens & & & & \\
\hline & Genistein & Human & 1, 10, and $100 \mathrm{nM}(4)$ & & Fraser et al. (2006) \\
\hline & & Boar & $0.001,0.01,0.1,1,10$, and $100 \mu \mathrm{M}(4)$ & & $\begin{array}{l}\text { Mohamed el et al. } \\
\text { (2011) }\end{array}$ \\
\hline & & Mouse & $1,10,100$, and $1000 \mathrm{nM}(3-6)$ & & $\begin{array}{l}\text { Adeoya-Osiguwa } \\
\text { et al. (2003) }\end{array}$ \\
\hline & Mycotoxins & & & & \\
\hline & ZEA & Boar & $125,187.5$, and $250 \mu \mathrm{M}(6)$ & Increased & $\begin{array}{l}\text { Tsakmakidis et al. } \\
\text { (2006) }\end{array}$ \\
\hline & $\alpha-Z O L$ & & $125, \mathbf{1 8 7 . 5}$, and $\mathbf{2 5 0} \boldsymbol{\mu M}(6)$ & & \\
\hline & $\beta-Z O L$ & Horse & $1 \mathrm{pM}-\mathbf{1 0 0} \boldsymbol{\mu M}$ & Decreased & Filannino et al. (2011) \\
\hline
\end{tabular}


Table 1 Continued.

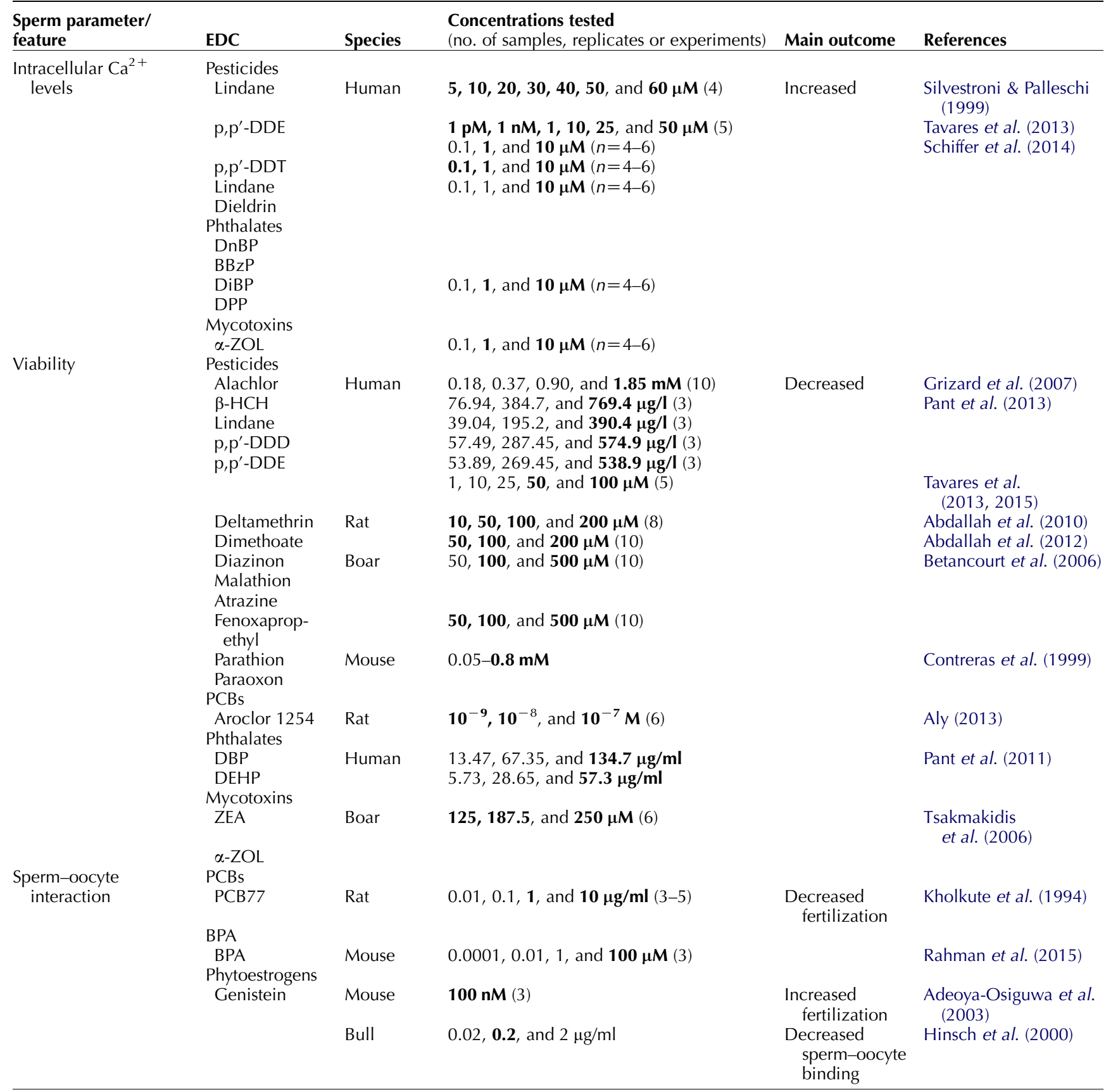

Concentrations in bold are the ones that induced the effects noted. BPA, bisphenol A; dioxins: TCDD, 2,3,7,8-tetrachlorodibenzo- $p$-dioxin; micotoxins: ZEA, zearalenone; $\alpha$-ZOL, $\alpha$-zearalenol; $\beta$-ZOL, $\beta$-zearalenol; $\alpha$-ZAL, $\alpha$-zearalanol; pesticides: $\beta$-HCH, $\beta$-hexachlorocyclohexane; PCB54, 2,2',6,6'-tetrachlorobiphenyl; PCB77, 3, 3', 4,4'-tetrachlorobiphenyl; phthalates: BBzP, benzyl butyl phthalate; DiBP, di-iso-butyl phthalate; DnBP, dibutyl phthalate; DPP, dipentyl phthalate.

organophosphates and alachlor (Table 1; Contreras et al. 1999, Grizard et al. 2007, Abdallah et al. 2010). Furthermore, co-incubation of spermatozoa with the potent antioxidants vitamin $\mathrm{C}$ and/or $\mathrm{E}$ has shown to prevent pesticide-induced effects (Abdallah et al. 2012).

Contrarily to organophosphates and pirethroids, organochlorine pesticides are extremely persistent in the environment. Among them, the major and most stable dichlorodiphenyl trichloroethane (DDT) metabolite, $p, p^{\prime}$-dichlorodiphenyl dichloroethylene $\left(p, p^{\prime}-D D E\right)$, has been the subject of multiple studies.

In vitro studies have shown that this compound, often used to control malaria-bearing mosquitoes in some countries (Aneck-Hahn et al. 2007), affects human sperm 
function at concentrations found in reproductive fluids, potentially compromising male fertility (Tavares et al. 2013, 2015). Several parameters such as motility, MMP, cellular ATP levels and acrosomal integrity were found reduced upon exposure to $\mathrm{p}, \mathrm{p}^{\prime}$-DDE whereas an elevation in the intracellular $\mathrm{Ca}^{2+}$ concentration $\left(\left[\mathrm{Ca}^{2+}\right]_{i}\right)$ was attributed to the activation of the plasma membrane $\mathrm{Ca}^{2+}$ channel Catsper (Tavares et al. 2013, 2015). Overall, $p, p^{\prime}-$ DDE primarily promoted $\mathrm{Ca}^{2+}$ influx, which, due to its high and constant nature, may have impaired many cell parameters given that $\mathrm{Ca}^{2+}$ is heavily involved not only in acrosome reaction (which, if prematurely triggered, will render sperm non-functional) but also in several other signaling pathways (JimenezGonzalez et al. 2006, Tavares et al. 2013, 2015). Accordingly, using $p, p^{\prime}$-DDE doses found in human semen and concentrations that were five- and tenfold higher, Pant et al. (2013) have reported a significant concentration and time-dependent decline in motility after $24 \mathrm{~h}$ of $\mathrm{p}, \mathrm{p}^{\prime}$-DDE exposure and decreased cell viability in vitro, although the latter was only observed at the higher doses tested. Furthermore, the same outcomes were found for the organochlorine pesticides $\beta$-hexachlorocyclohexane $(\beta-\mathrm{HCH})$, lindane, and $p, p^{\prime}-$ dichlorodiphenyl dichloroethane ( $\mathrm{p}, \mathrm{p}^{\prime}$-DDD; Pant et al. 2013). Moreover, others have detected an increase in $\left[\mathrm{Ca}^{2+}\right]_{i}$ due to $\mathrm{Ca}^{2+}$ influx from the surrounding media in human spermatozoa upon exposure to the organochlorine lindane. However, in this case, lindane was able to inhibit not only the acrosome reaction but also the sperm responsiveness to progesterone, a physiological agonist of the acrosome reaction (Silvestroni et al. 1997, Silvestroni \& Palleschi 1999). Recently, the effects of almost 100 EDCs on human sperm were tested and not all were able to induce significant changes in intracellular $\mathrm{Ca}^{2+}$ levels. Moreover, those that did (e.g., pesticides, phthalates, mycotoxin, among others; Table 1) were not always acting via the Catsper channel (Schiffer et al. 2014). In accordance, others have found no effects on $\left[\mathrm{Ca}^{2+}\right]_{i}$ upon bisphenol $A$ and $2,3,7,8-$ tetrachlorodibenzo- $p$-dioxin (TCDD) exposure in human sperm (Luconi et al. 2001, Mota et al. 2012).

Fenoxaprop-ethyl, atrazine, and organophosphates such as parathion and its active metabolite paraoxon were also found to induce the acrosome reaction in vitro (Contreras et al. 1999, Maravilla-Galván et al. 2009). However, before spermatozoa become able to undergo the acrosome reaction, they must undergo capacitation, a process without which they do not become functionally competent, and little is known about the potential effects of pesticides in this process. Apart from $p, p^{\prime}-D D E$ and atrazine, which were able to suppress capacitation markers in human and boar sperm (Maravilla-Galván et al. 2009, Tavares et al. 2015), and fenoxaprop-ethyl, which was found to increase capacitation (MaravillaGalván et al. 2009), to our knowledge no other in vitro studies have been performed. Nevertheless, the concentrations used to obtain such findings cannot be considered environmentally relevant.

\section{Dioxins, PCBs and PAHs}

\section{Polychlorinated dibenzo-p-dioxins}

PCDDs are a well-established family of POPs commonly referred to as dioxins. The representative compound TCDD has been originated from industrial sources as an unintended by-product in the production of certain chlorophenols or chlorophenoxy acid herbicides, waste incineration, metal production and fossil fuel and wood combustion (Harnly et al. 1995). Considered the most powerful biological agent ever made by man, it interacts primarily with the aryl hydrocarbon receptor (AhR; Buchanan et al. 2000), a cytosolic-ligand transcription factor that upon binding translocates to the nucleus where it heterodimerizes with the aryl hydrocarbon nuclear translocator and elicits (anti)estrogenic responses in many tissues (Buchanan et al. 2000, Boverhof et al. 2006). In fact, TCDD has been used as a prototype for a great class of halogenated aromatic hydrocarbons on the basis that other related congeners will show the same toxicity of TCDD but with altered potency, determined by their relative AhR agonism and pharmacokinetics (Van den Berg et al. 2006).

Despite the extensive data generated over the years pointing toward male reproductive system susceptibility to dioxin exposure, in particular TCDD, studies have mostly focused on possible genomic effects (Mably et al. 1992, Jin et al. 2008, Mocarelli et al. 2008, 2011). Notwithstanding, Fisher et al. (2005) have described a dose-dependent loss of MMP in epididymal sperm due to increased ROS production in mice exposed to TCDD, an effect that was not perceptible in spermatozoa from AhR knockout mice but that was detected in mouse epididymal spermatozoa after 45 min of direct exposure to 1 and $5 \mathrm{nM}$ TCDD. Taken together, these findings showed not only the involvement of AhR in mediating TCDD-induced oxidative stress in the male reproductive system but also that AhR is capable of mediating nongenomic TCDD-induced effects even though many of AhR-mediated effects involve alterations at the gene expression level (Fisher et al. 2005). However, contrarily to the results obtained by these authors, a recent study showed no alteration in human sperm mitochondrial function following $24 \mathrm{~h}$ of in vitro exposure to similar and higher TCDD doses (Mota et al. 2012). We may therefore infer that either mouse sperm mitochondria diverge greatly from their human sperm counterparts or human sperm are more resistant to TCDD, which is in fact suggested by the features of the human AhR, more closely related to the allele existent in TCDD-resistant DBA/2J mice (Mota et al. 2012). Additionally, no direct effects were observed on human sperm viability, capacitation, acrosome reaction and motility even at 
$1 \mu \mathrm{M}$ TCDD (Mota et al. 2012), a concentration far higher than background levels (Tsutsumi et al. 1998). Accordingly, Hanf et al. (1992) also reported the lack of in vitro effects of various dioxin congeners on human sperm motility over a period of $60 \mathrm{~h}$. Altogether, both reports seem to suggest that several aspects of human sperm functionality would not be compromised when in contact with naturally occurring levels of dioxins in both seminal fluid and female genital tract secretions (Hanf et al. 1992, Mota et al. 2012). It seems that the reported effects of TCDD on human sperm parameters that may affect male fertility may result from changes during spermatogenesis and/or during the transit through the male reproductive tract rather than through a direct exposure (Mota et al. 2012).

\section{Polychlorinated biphenyls}

PCBs are a class of compounds that include a total of 209 different congeners with varying patterns of toxicity. A small group of 12 congeners known as dioxin-like or co-planar PCBs resemble the TCDD molecular conformation, binding to $\mathrm{AhR}$ and presenting the greatest toxicity of all PCBs (Safe 1994). The non-dioxin-like congeners, on the other hand, although not believed to primarily interact with this receptor, are still able to induce toxic effects on diverse systems as demonstrated by manifold in vivo studies, potentially acting via the estrogen receptor (Hansen 1999, Pflieger-Bruss et al. 2006a).

For a long time, PCBs were being generated through industrial processes and used in hydraulic fluids, capacitors, lubricants, plasticizers, and electrical insulators (Hauser et al. 2002). Although banned, they continue to enter the environment due to leaks in equipment-containing PCBs still in use or inadequate clearance practices and via de novo formation through high-temperature procedures such as incineration.

Much concern has been raised regarding the reproductive health consequences of exposure to the environmental levels of PCBs as they have been associated with lower sperm quality (Bush et al. 1986, Hauser et al. 2002, 2003) and reduced couple fecundity (Buck Louis et al. 2013). Furthermore, although this was not true for every case, a number of human studies have pointed to inverse relationships between blood serum or seminal plasma PCBs within the range of current levels for most European populations and standard sperm parameters, particularly with sperm motility, which was found to be more vulnerable to PCB exposure than sperm concentration or morphology (Bush et al. 1986, Hauser et al. 2003). Supporting these findings, non-genomic studies have shown a decrease in motility (Table 1 ) after exposure to low levels of $2,2^{\prime}, 6,6^{\prime}$ tetrachlorobiphenyl (PCB54; Roediger et al. 1989) and 2,4,4'-trichlorobiphenyl (PCB28), 2,4,6-trichlorobiphenyl (PCB30), and 2,3', 4, 4',5-pentachlorobiphenyl (PCB118; Yurdakok et al. 2015) in human and bull spermatozoa. Moreover, porcine sperm treated with an organochlorine mixture containing several PCB congeners plus a panoply of other compounds, including pesticides, were also found to reduce both motility and viability in vitro (Campagna et al. 2002). In sharp contrast, exposure to reasonably high concentrations $(2-20 \mu \mathrm{g} / \mathrm{ml})$ of the non-dioxin-like $2,2^{\prime}, 4,4^{\prime}, 5,5^{\prime}$-hexachlorobiphenyl (PCB153) and dioxinlike PCB congeners $118,126\left(3,3^{\prime}, 4,4^{\prime}, 5\right.$-pentachlorobiphenyl) and $77\left(3,3^{\prime}, 4,4^{\prime}\right.$-tetrachlorobiphenyl) failed to produce any effect on human sperm movement, viability and spontaneous acrosome reaction after $5 \mathrm{~h}$ of incubation (Pflieger-Bruss et al. 2006a,b). Nevertheless, using a validated in vitro 3-day approach (Tavares et al. 2013, 2015) that better mimics sperm exposure to EDCs in the female reproductive tract, we found that PCB77 was able to reduce both motility and mitochondrial function in human normozoospermic samples before promoting cell death after $48 \mathrm{~h}$ of exposure at the highest concentration, as shown in Fig. 1. The fact that a greater incubation period was used may explain the discrepancies between these studies and highlights the types of experimental approaches that can be undertaken with human samples.

Besides affecting conventional sperm parameters and, in some cases, acrosomal status (Roediger et al. 1989), PCBs may also interfere with nuclear DNA integrity (Table 1). A potential mechanism whereby PCBs may produce such damage is oxidative stress, which has been already reported to occur in rat sperm exposed to Aroclor 1254, a commercial mixture of PCBs (Aly 2013). In fact, in this case, direct exposure to low Aroclor 1254 concentrations $\left(10^{-9}, 10^{-8}\right.$, or $\left.10^{-7} \mathrm{M}\right)$ for $3 \mathrm{~h}$ not only induced oxidative stress and increased sperm DNA damage but also increased lipid peroxidation and decreased sperm motility, ATP levels, acrosome reaction, MMP and viability. Furthermore, Aroclor 1254 promptly promoted cytochrome $c$ release and caspase- 3 activation, thus culminating in mitochondriamediated apoptosis (Aly 2013). Interestingly, Kholkute et al. (1994) have also reported an inhibition of fertilization rates when capacitated sperm and oocytes obtained from non-exposed mice were cultured in vitro in a PCB77-containing medium.

\section{Polycyclic aromatic hydrocarbons}

PAHs comprise a wide range of organic compounds with multiple aromatic rings. In general, $\mathrm{PAH}$ are present in fossil fuels (oil and coal), tar deposits and overcooked food and are generated when incomplete combustion of organic material occurs. Exposure to these compounds has been correlated with a higher risk of infertility as men with idiopathic infertility and abnormal sperm parameters were shown to have increased levels of urinary PAH metabolites when compared to controls (Xia et al. 2009). Furthermore, non-genomic studies (Table 1) have shown that although modest effects on human sperm motility were observed after immediate 
exposure to diesel particulate extracts, a marked alteration in all CASA parameters reflecting sperm movement and hyperactivation (motility, curvilinear velocity, straight line velocity, linearity, and amplitude of lateral head displacement) was elicited upon $18 \mathrm{~h}$ of exposure (Fredricsson et al. 1993).

Owing to its reprotoxic and carcinogenic potential, benzo[a]pyrene $(\mathrm{B}[\mathrm{a}] \mathrm{P})$ has received much attention,
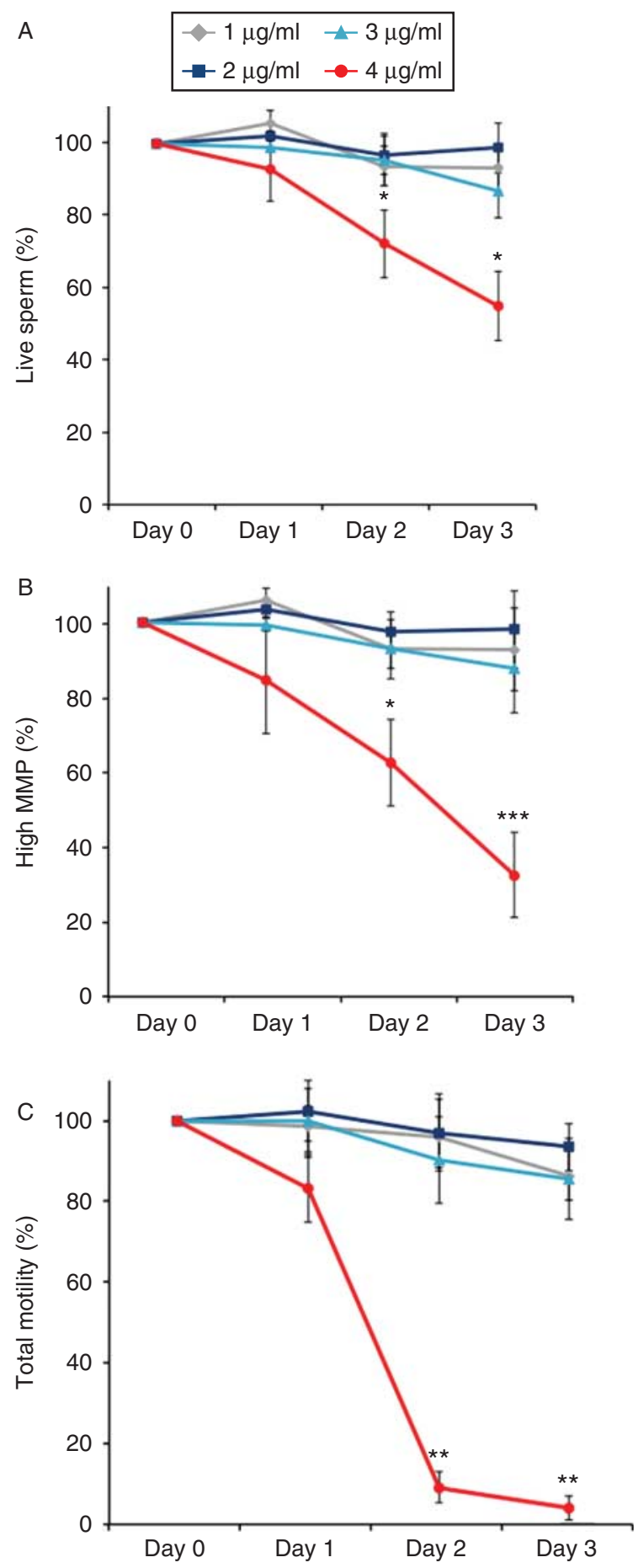

Reproduction (2016) 151 R1-R13 being widely used as a surrogate for $\mathrm{PAH}$ exposure. Studies performed with B[a]P have, so far, mainly focused on the formation of DNA adducts, which may subsequently lead to DNA damage. B[a]P may be converted into reactive metabolites, such as benzo[a]pyrene-7,8-diol-9,10-epoxide (BPDE) that binds covalently to DNA (Pelkonen \& Nebert 1982), or can be metabolized by the aldoketo reductase pathway, promoting oxidative stress and the establishment of catechol DNA adducts (Penning 2004). Either way, metabolites react with a multitude of molecules and thus exposure to $\mathrm{B}[\mathrm{a}] \mathrm{P}$ may disturb many cellular processes. Previous reports probably reflecting the genomic effects of $\mathrm{B}[\mathrm{a}] \mathrm{P}$ have described DNA lesions in mouse sperm after in vivo treatment (Olsen et al. 2010) and similar non-genomic BPDE-induced damage in human sperm following in vitro exposure (Sipinen et al. 2010). Surprisingly, B [a]P and BPDE-related DNA fragmentation were also observed in human sperm in vitro as measured by the alkaline comet assay. The finding that DNA damage may occur without DNAadduct formation following direct $\mathrm{B}[\mathrm{a}] \mathrm{P}$ exposure in human sperm suggests a $\mathrm{B}$ [a]P metabolism independent of BPDE conversion (Sipinen et al. 2010). Additionally, $\mathrm{B}[\mathrm{a}] \mathrm{P}$ was also able to directly increase the number of human spermatozoa with structural chromosome aberrations, but only when metabolically activated by rat liver S9 (Watanabe \& Kamiguchi 2001).

However, not many studies have evaluated the effects of $\mathrm{B}[\mathrm{a}] \mathrm{P}$ on other sperm parameters that indicate functional status and fertilizing potential. With that in mind, Mukhopadhyay et al. (2010) found that B[a]P directly affected sperm functional competence in human normozoospermic samples as evidenced by increased hyperactivation and premature acrosomal reaction in vitro. Furthermore, high exposure to $\mathrm{B}[\mathrm{a}] \mathrm{P}(500 \mu \mathrm{M}, 1 \mathrm{~h})$ was also found to directly increase human sperm

Figure 1 Effect of continuous exposure to different PCB77 concentrations on sperm parameters as an example of experimental in vitro approaches using human samples. (A) Viability, (B) high mitochondrial membrane potential (MMP), and (C) total motility (progressive + in situ motility) were assessed by the LIVE/DEAD Sperm Viability Kit, mitochondrial JC-1 dye (Molecular Probes, Eugene, OR, USA) and phase contrast microscopy respectively (Tavares et al. 2015). Human normozoospermic samples were continuously exposed to PCB77 for 3 days at $37^{\circ} \mathrm{C}$ and $5 \% \mathrm{CO}_{2}$ in a PBS-based medium supplemented with $0.9 \mathrm{mM} \mathrm{CaCl}_{2}, 0.5 \mathrm{mM} \mathrm{MgCl}_{2}, 5 \mathrm{mM}$ D-glucose, $1.0 \mathrm{mM}$ Na-pyruvate, $10.0 \mathrm{mM}$ Na-lactate, $0.3 \%(\mathrm{w} / \mathrm{v}) \mathrm{BSA}$, and $1 \%(\mathrm{v} / \mathrm{v})$ penicillin/streptomycin, $\mathrm{pH} 7.2-7.4$, optimal to maintain spermatozoa for extended periods (Tavares et al. 2013, 2015). Solvent controls were performed by adding $0.5 \%(\mathrm{v} / \mathrm{v})$ DMSO. Daily assessments were performed for each parameter in the same samples $(n=6)$ and medium was changed every day following centrifugation ( $528 \mathrm{~g}$, $10 \mathrm{~min}$ ). Interestingly, sperm motility was affected prior to high MMP decline. Results represent mean percentage \pm S.E.M. relative to the respective control (i.e. $\%$ in each PCB77 concentration/\% in the vehicle DMSO $\times 100) .{ }^{*} P<0.05,{ }^{* *} P<0.01$, and ${ }^{* * *} P<0.001$ symbolize significant differences when compared to the controls. 
intracellular ROS and induce nuclear DNA damage, effects that were significantly counteracted with the addition of a Chilean propolis extract described to possess antioxidant properties (Russo et al. 2006). Yet, membrane lipid peroxidation was unaffected upon B [a]P treatment (Russo et al. 2006).

\section{Phthalates and bisphenol A}

Other compounds considered of interest in male reproduction are the diesters of 1,2-benzenedicarboxylic acid (phthalic acid), commonly identified as phthalates. They are usually used as plasticizers in a wide range of polyvinyl chloride products, including raincoats and footwear, toys, food packing and medical devices, and as solvents in personal care goods, coatings, and polishes (Fredricsson et al. 1993, Pant et al. 2011). Owing to their widespread use and non-covalent binding to products, phthalates can be constantly released and easily dispersed in the environment, being detected in individual populations worldwide (Duty et al. 2003, Pant et al. 2011, Jurewicz et al. 2013). Although these compounds have short half-lives (hours) and do not accumulate in the body, chronic exposure to low levels obtained through diet and commonly used products can provide continuous steady state concentrations in the living organisms (Duty et al. 2003).

In in vivo animal studies, exposure to phthalates has shown to adversely affect male reproduction, but data in humans have been inconsistent. Although a number of studies have associated urinary and seminal phthalate levels to a deterioration of important sperm parameters in environmentally exposed men, others failed to detect any alterations (Duty et al. 2003, Jonsson et al. 2005, Pant et al. 2011, Jurewicz et al. 2013). As significant temporal within-person variation has been described in metabolite concentrations determined in spot, first morning and 24-h urine samples, this discrepancy may be attributed, at least in part, to both variable phthalate levels and their short half-lives (Preau et al. 2010). To this extent, in vitro studies are an excellent option to study the effects of phthalate exposure and are also crucial in verifying their potential non-genomic actions in spermatozoa. As such, Pant et al. (2011) have tested the effects of two specific phthalates (di(2-ethyl-hexyl) phthalate (DEHP) and di- $n$-butyl phthalate (DBP)) on human sperm motility and viability using the concentrations detected in seminal samples from epidemiological findings (5.73 and $13.47 \mu \mathrm{g} / \mathrm{ml}$ for DEHP and DBP respectively) and concentrations that were five- or tenfold higher. They found that both EDCs induced a concentration- and time-dependent decrease in sperm viability, but cytotoxicity was only obvious at the maximum concentrations tested and following $96 \mathrm{~h}$ of exposure. However, when motility was monitored, a reduction at all DEHP doses was observed only after $12 \mathrm{~h}$ of in vitro exposure, but for DBP the same effect was only detected after an 18-h incubation period. Consistently, a more than $50 \%$ inhibition of motility was detected after 24 and $48 \mathrm{~h}$ of exposure to the environmental DEHP and DBP concentrations, respectively, confirming the higher toxicological potential of DEHP (Pant et al. 2011). Fredricsson et al. (1993) have also studied the effects of various phthalates on human sperm motility using a CASA system and observed that the various movement variables analyzed (curvilinear velocity, straight line velocity, and linearity) were differently influenced by the different phthalates. Additionally, they concluded that human normozoospermic samples were more susceptible to the action of DEHP and DBP in vitro, with the former being the most potent. In contrast, spermatozoa were found to better resist dimethyl phthalate (DMP) exposure than di-ethyl phthalate (DEP) and di-n-octyl phthalate (DOP).

Importantly, recent data have also indicated the presence of important levels of phthalates such as DEHP and its hydrolyzed metabolite mono(2-ethylhexyl) phthalate not only in media used for sperm washing and isolation but also in media used to perform IVF and in added protein sources (human serum albumin or serum substitute; Takatori et al. 2012). Such evidence reinforces the need of assessing the effects of phthalates in vitro on several sperm functional parameters other than motility, viability and, recently, $\mathrm{Ca}^{2+}$ levels (Table 1), which to our knowledge were the only parameters evaluated so far.

Another compound with potential estrogenic activity is bisphenol A, which is used in epoxy resins and polycarbonate plastics needed to produce baby bottles and plastic containers, among other products. Similarly to phthalates, BPA is heavily produced annually and can constantly leach into the environment.

In vitro studies have shown no effect of BPA in inducing DNA damage (Bennetts et al. 2008), altering $\left[\mathrm{Ca}^{2+}\right]_{i}$ and affecting spontaneous or progesteroneinduced acrosome reaction in human sperm directly (Luconi et al. 2001). Nevertheless, in a very recent study Rahman et al. (2015) have shown that high BPA exposure $(100 \mu \mathrm{M})$ for a relative short period of time directly decreased motility and motion kinematics by reducing ATP levels in mice sperm in vitro. Furthermore, a decrease in capacitation and premature acrosome reaction were found at $100 \mu \mathrm{M} \mathrm{BPA}$, ultimately resulting in decreased fertilization and blastocyst formation rates (Table 1).

\section{Natural compounds: sources of exposure and effects on spermatozoa}

\section{Phytoestrogens and mycotoxins}

Among the natural-occurring EDCs, phytoestrogens and mycotoxins have been the most studied. Phytoestrogens are known to be produced by plants and are mainly 
consumed through diet because they are present in legumes, fruits, cereal, nuts, and oilseeds (Mazur \& Adlercreutz 2000). These compounds have raised a certain level of concern due to the fact that they are able to bind to estrogen receptors, acting as agonists or as antagonists (Mohamed el et al. 2011). Because of the high prevalence and risk of exposure to such compounds, several studies have been performed to assess their possible effects on male fertility.

One of the most studied phytoestrogens is genistein, an isoflavone found in soy and legumes (Mazur \& Adlercreutz 2000). Genistein exposure in human adult populations worldwide may vary according to individual eating habits, but in a rich-consuming soy diet, levels have been determined to range between 1.5 and $4.1 \mathrm{mg} /$ day per person (Fukutake et al. 1996).

It has been shown that low doses of genistein in vitro are able to accelerate sperm capacitation and acrosome reaction in vitro (Table 1 ), not only in humans (Fraser et al. 2006) but also in mice (Adeoya-Osiguwa et al. 2003) and boar (Mohamed el et al. 2011). Because prematurely acrosome-reacted sperm cannot fertilize an oocyte, this compound could have an undesirable effect on fertility. On the other hand, Hinsch et al. (2000) have also shown that genistein may inhibit progesteroneinduced acrosome reaction and binding to the oocyte zona pellucida, as determined by the hemizona assay, however, without compromising motility and viability in cryopreserved bull sperm. Nevertheless, IVF experiments using mouse spermatozoa that were pre-incubated with $0.1 \mu \mathrm{M}$ genistein have also been shown to increase the percentage of fertilized oocytes determined by the resumption of the second meiotic division and the presence of decondensed sperm heads, therefore suggesting the stimulation of sperm fertilizing ability (Adeoya-Osiguwa et al. 2003).

Mycotoxins, on the other hand, are secondary metabolites produced by some fungi, known as molds (Richard 2007), and, as is the case for phytoestrogens, animal and human populations are exposed to such compounds via dietary intake (Massart \& Saggese 2010). Some of the main mycotoxins are aflatoxins, deoxynivalenol, fumonisins, zearalenone (ZEA), T-2 toxin, ochratoxin, and certain ergot alkaloids (Richard 2007). The most studied mycotoxin, ZEA, is a nonsteroidal estrogenic mycotoxin produced by Fusarium fungi (Zinedine et al. 2007) that contaminates corn, maize, barley, oats, wheat, sorghum, sesame, millet, and rice (Massart \& Saggese 2010). On oral intake, ZEA is rapidly absorbed and metabolized in the liver and intestine into different metabolites such as $\alpha$ - and/or $\beta$-zearalenol ( $\alpha$ - and $\beta$-ZOL), $\alpha$-and/or $\beta$-zearalanol, and zearalanone (ZAN), which can be conjugated with glucoronic acid (Massart \& Saggese 2010). Like phytoestrogens, ZEA has a similar structure to $E_{2}$, acting as an estrogen receptor agonist (Sambuu et al. 2011). The effect of this mycotoxin has been studied in species that are the most affected by ZEA such as porcine (Tsakmakidis et al. 2006, Sambuu et al. 2011) and equine (Minervini et al. 2010, Filannino et al. 2011). The in vitro studies performed in boar have reported the toxic effects of ZEA and its derivatives on sperm quality and function (Table 1), impairing its fertilizing capacity. Tsakmakidis et al. (2006) showed that exposure to ZEA led to a reduction in sperm viability, progressive motility and the percentage of sperm capable to undergo acrosome reaction. Moreover, in 2008, the same group revealed that ZEA also affected sperm chromatin integrity (Tsakmakidis et al. 2008). Contrarily to boar, horse sperm was thought to be less susceptible to the effects of ZEA. However, it has been found that the ZEA derivate, $\alpha-Z O L$, decreased the percentage of motile sperm, changed the motility characteristic of the remaining motile sperm and induced the acrosome reaction (Filannino et al. 2011). Furthermore, a different study on chromatin structure stability showed that ZEA, $\alpha-Z O L$, and $\beta-Z O L$ are more toxic than the other derivatives on equine sperm chromatin structure (Minervini et al. 2010).

\section{Conclusions and future perspectives}

Many EDCs have been shown to interact with preexisting signaling pathways in spermatozoa from diverse mammalian species and produce undesirable effects, contributing to a decrease in male fertility. Indeed, EDCs may affect sperm parameters such as motility, mitochondrial function, acrosomal status and/or DNA integrity, among others, via different modes of action, and this will inevitably have repercussions in terms of fertilization success and proper delivery of intact genetic information to the progeny.

Although little is known about EDC levels in reproductive fluids and secretions in heavily exposed populations (for instance, due to extremely high contamination, e.g., the Seveso disaster, or occupational exposure), they are expected to be higher than in populations exposed to environmental levels. Regardless, even though some authors may have used fairly higher concentrations in their in vitro experimental settings, one should always keep in mind that human and animal populations (and therefore spermatozoa) are not directly exposed to one but rather to a cocktail of environmental EDCs (Tsutsumi et al. 1998, Younglai et al. 2002, Drbohlav et al. 2005) and limited evidence exists about the possible synergistic effects of such toxicants on sperm functional parameters, an issue that should be seriously taken into account in further studies, although the unveiling of specific mechanistic effects of each individual EDC may be dampened in such experimental settings. Thus, when acting together, more environmentally relevant concentrations of several EDC may eventually hamper human sperm function and thus compromise male fertility. 
Finally, studies performed in rodents have shown a new mode of EDC action with worrisome conclusions: EDCs may have the ability to reprogram the male germline during fetal gonadal sex determination and promote a transgenerational effect in which initial exposure effects may be transmitted to future generations in the absence of further exposure (Anway et al. 2006). Although there may be strain-specific effects, it has been postulated that EDCs may promote a permanent alteration in the germline epigenome that escapes epigenetic reprogramming at fertilization and early development. This germline epigenetic inheritance could alter the embryonic epigenome so individuals will be susceptible to develop adult onset diseases across generations, such as testis pathologies and a reduced fertilizing capability phenotype (Anway et al. 2006), meaning that aspects of male infertility may be perpetuated across multiple generations. This represents a totally new and promising research field that remains largely unexplored. Whether this occurs in humans is something that still needs to be verified.

\section{Declaration of interest}

The authors declare that there is no conflict of interest that could be perceived as prejudicing the impartiality of the review.

\section{Funding}

Center for Neuroscience and Cell Biology (CNC) was supported by Portuguese National Funding Agency for Science and Technology (Fundação para a Ciência e Tecnologia - FCT) through grants PEst-C/SAU/LA0001/2011 and Pest-C/SAU/ LA0001/2013-2014. M Correia and P C Mota are recipients of $\mathrm{PhD}$ (SFRH/BD/51681/2011) and PD (SFRH/BPD/ 74252/2010) fellowships from FCT respectively.

\section{Acknowledgements}

The authors would like to acknowledge all members of the Biology of Reproduction and Stem Cell Group, particularly Sandra Amaral, Marta Baptista, and Andreia Silva for many useful discussions. J Saints is also acknowledged for language assistance and manuscript revision.

\section{References}

Abdallah FB, Hamden K, Galeraud-Denis I, El Feki A \& Keskes-Ammar L 2010 An in vitro study on reproductive toxicology of Deltamethrin on rat spermatozoa. Andrologia 42 254-259. (doi:10.1111/j.1439-0272.2009. 00986.x)

Abdallah FB, Fetoui H, Zribi N, Fakfakh F \& Ammar-Keskes L 2012 Antioxidant supplementations in vitro improve rat sperm parameters and enhance antioxidant enzyme activities against dimethoate-induced sperm damages. Andrologia 44 272-279. (doi:10.1111/j.1439-0272. 2011.01177.x)
Adeoya-Osiguwa SA, Markoulaki S, Pocock V, Milligan SR \& Fraser LR $200317 \beta$-Estradiol and environmental estrogens significantly affect mammalian sperm function. Human Reproduction 18 100-107. (doi:10.1093/humrep/deg037)

Aly HÁ 2013 Aroclor 1254 induced oxidative stress and mitochondria mediated apoptosis in adult rat sperm in vitro. Environmental Toxicology and Pharmacology 36 274-283. (doi:10.1016/j.etap.2013.04.006)

Amaral A, Lourenço B, Marques M \& Ramalho-Santos J 2013 Mitochondria functionality and sperm quality. Reproduction $\mathbf{1 4 6}$ R163-R174. (doi:10.1530/REP-13-0178)

Aneck-Hahn NH, Schulenburg GW, Bornman MS, Farias P \& De Jager C 2007 Impaired semen quality associated with environmental DDT exposure in young men living in a malaria area in the Limpopo Province, South Africa. Journal of Andrology 28 423-434. (doi:10.2164/jandrol. 106.001701)

Anway MD, Memon MA, Uzumcu M \& Skinner MK 2006 Transgenerational effect of the endocrine disruptor vinclozolin on male spermatogenesis. Journal of Andrology 27 868-879. (doi:10.2164/jandrol.106.000349)

Auger J, Kunstmann JM, Czyglik F \& Jouannet P 1995 Decline in semen quality among fertile men in Paris during the past 20 years. New England Journal of Medicine 332 281-285. (doi:10.1056/ NEJM199502023320501)

Bennetts LE, De Iuliis GN, Nixon B, Kime M, Zelski K, McVicar CM, Lewis SE \& Aitken RJ 2008 Impact of estrogenic compounds on DNA integrity in human spermatozoa: evidence for cross-linking and redox cycling activities. Mutation Research 641 1-11. (doi:10.1016/ j.mrfmmm.2008.02.002)

Betancourt M, Reséndiz A \& Fierro EC 2006 Effect of two insecticides and two herbicideson the porcine sperm motility patterns using computerassisted semen analysis (CASA) in vitro. Reproductive Toxicology 22 508-512. (doi:10.1016/j.reprotox.2006.03.001)

Bjørling-Poulsen M, Andersen HR \& Grandjean P 2008 Potential developmental neurotoxicity of pesticides used in Europe. Journal of Environmental Health 7 50. (doi:10.1186/1476-069X-7-50)

Boverhof DR, Kwekel JC, Humes DG, Burgoon LD \& Zacharewski TR 2006 Dioxin induces an estrogen-like, estrogen receptor-dependent gene expression response in the murine uterus. Molecular Pharmacology 69 1599-1606. (doi:10.1124/mol.105.019638)

Buchanan DL, Sato T, Peterson RE \& Cooke PS 2000 Antiestrogenic effects of 2,3,7,8-tetrachlorodibenzo- $p$-dioxin in mouse uterus: critical role of the aryl hydrocarbon receptor in stromal tissue. Toxicological Sciences 57 302-311. (doi:10.1093/toxsci/57.2.302)

Buck Louis GM, Sundaram R, Schisterman EF, Sweeney AM, Lynch CD, Gore-Langton RE, Maisog J, Kim S, Chen Z \& Barr DB 2013 Persistent environmental pollutants and couple fecundity: the LIFE study. Environmental Health Perspectives 121 231-236. (doi:10.1289/ehp. 1205301)

Bush B, Bennett AH \& Snow JT 1986 Polychlorobiphenyl congeners, $\mathrm{p}, \mathrm{p}^{\prime}-\mathrm{DDE}$, and sperm function in humans. Archives of Environmental Contamination and Toxicology 15 333-341. (doi:10.1007/BF01066399)

Campagna C, Guillemette C, Paradis R, Sirard MA, Ayotte P \& Bailey JL 2002 An environmentally relevant organochlorine mixture impairs sperm function and embryo development in the porcine model. Biology of Reproduction 67 80-87. (doi:10.1095/biolreprod67.1.80)

Carlsen E, Giwercman A, Keiding N \& Skakkeblek NE 1992 Evidence for decreasing quality of semen during past 50 years. BMJ 305 609-613. (doi:10.1136/bmj.305.6854.609)

Chikuni O, Skare JU, Nyazema N \& Polder A 1991 Residues of organochlorine pesticides in human milk from mothers living in the greater Harare area of Zimbabwe. Central African Journal of Medicine 37 136-141.

Contreras HR, Badilla J \& Bustos-Obregón E 1999 Morphofunctional disturbances of human sperm after incubation with organophosphate pesticides. Biocell 23 135-141.

Drbohlav P, Jirsová S, Masata J, Jech L, Bencko V, Omelka M \& Zvárová J 2005 Relationship between the levels of toxic polychlorinated biphenyls in blood and follicular fluid of sterile women. Ceská Gynekologie 70 377-383.

Duty SM, Singh NP, Silva MJ, Barr DB, Brock JW, Ryan L, Herrick RF, Christiani DC \& Hauser R 2003 The relationship between environmental 
exposures to phthalates and DNA damage in human sperm using the neutral comet assay. Environmental Health Perspectives 111 1164-1169. (doi:10.1289/ehp.5756)

Filannino A, Stout TA, Gadella BM, Sostaric E, Pizzi F, Colenbrander B, Dell'Aquila ME \& Minervini F 2011 Dose-response effects of estrogenic mycotoxins (zearalenone, $\alpha$ - and $\beta$-zearalenol) on motility, hyperactivation and the acrosome reaction of stallion sperm. Reproductive Biology and Endocrinology 9 134. (doi:10.1186/1477-7827-9-134)

Fisher MT, Nagarkatti M \& Nagarkatti PS 2005 Aryl hydrocarbon receptordependent induction of loss of mitochondrial membrane potential in epididydimal spermatozoa by 2,3,7,8-tetrachlorodibenzo- $p$-dioxin (TCDD). Toxicology Letters 157 99-107. (doi:10.1016/j.toxlet.2005. 01.008)

Fraser LR, Beyret E, Milligan SR \& Adeoya-Osiguwa SA 2006 Effects of estrogenic xenobiotics on human and mouse spermatozoa. Human Reproduction 21 1184-1193. (doi:10.1093/humrep/dei486)

Fredricsson B, Möller L, Pousette A \& Westerholm R 1993 Human sperm motility is affected by plasticizers and diesel particle extracts. Pharmacology \& Toxicology 72 128-133. (doi:10.1111/j.1600-0773. 1993.tb00303.x)

Fukutake M, Takahashi M, Ishida K, Kawamura H, Sugimura T \& Wakabayashi K 1996 Quantification of genistein and genistin in soybeans and soybean products. Food and Chemical Toxicology 34 457-461. (doi:10.1016/0278-6915(96)87355-8)

Grizard G, Ouchchane L, Roddier H, Artonne C, Sion B, Vasson MP \& Janny L 2007 In vitro alachlor effects on reactive oxygen species generation, motility patterns and apoptosis markers in human spermatozoa. Reproductive Toxicology 23 55-62. (doi:10.1016/j.reprotox. 2006.08.007)

Guillette LJ Jr 1994 Endocrine-disrupting environmental contaminants and reproduction: lessons from the study of wildlife. In Women's Health Today: Perspectives on Current Research and Clinical Practice. Selected proceedings of XIV World Congress of Gynecology and Obstetrics, pp 201-207. Eds DR Popkin \& LJ Peddle. Parthenon: New York.

Hanf V, Brunner H, Haimovici F, Tinneberg HR, Hagenmaier H \& Anderson D 1992 Influence of various dioxins on in vitro motility of human sperm. Chemosphere 25 1049-1052. (doi:10.1016/0045-6535 (92)90105-Z)

Hansen LG 1999 In The Ortho Side of PCBs: Occurrence and Disposition, pp 7-20. Boston: Kluwer Academic Publishers.

Harnly M, Stephens R, McLaughlin C, Marcotte J, Petreas M \& Goldman L 1995 Polychlorinated dibenzo- $p$-dioxin and dibenzofuran contamination at metal recovery facilities, open burn sites, and a railroad car incineration facility. Environmental Science \& Technology 29 677-684. (doi:10.1021/es00003a015)

Hauser R, Altshul L, Chen Z, Ryan L, Overstreet J, Schiff I \& Christiani DC 2002 Environmental organochlorines and semen quality: results of a pilot study. Environmental Health Perspectives 110 229-233. (doi:10.1289/ ehp.02110229)

Hauser R, Chen Z, Pothier L, Ryan L \& Altshul L 2003 The relationship between human semen parameters and environmental exposure to polychlorinated biphenyls and p, $\mathrm{p}^{\prime}$-DDE. Environmental Health Perspectives 111 1505-1511. (doi:10.1289/ehp.6175)

Hinsch KD, Aires V, Hägele W \& Hinsch E 2000 In vitro tests for essential sperm functions using the phyto-oestrogen genistein as a test substance. Andrologia 32 225-231. (doi:10.1046/j.1439-0272.2000.00389.x)

Jimenez-Gonzalez C, Michelangeli F, Harper CV, Barratt CLR \& Publicover SJ 2006 Calcium signalling in human spermatozoa: a specialized 'toolkit' of channels, transporters and stores. Human Reproduction Update 12 253-267. (doi:10.1093/humupd/dmi050)

Jin $\mathbf{M H}$, Ko HK, Hong CH \& Han SW 2008 In utero exposure to 2,3,7,8tetrachlorodibenzo- $p$-dioxin affects the development of reproductive system in mouse. Yonsei Medical Journal 49 843-850. (doi:10.3349/ymj. 2008.49.5.843)

Jonsson BA, Richthoff J, Rylander J, Giwercman A \& Hagmar L 2005 Urinary phthalate metabolites and biomarkers of reproductive function in young men. Epidemiology 16 487-493. (doi:10.1097/01.ede. $0000164555.19041 .01)$

Jurewicz J, Radwan M, Sobala W, Ligocka D, Radwan P, Bochenek M, Hawuła W, Jakubowski L \& Hanke W 2013 Human urinary phthalate metabolites level and main semen parameters, sperm chromatin structure, sperm aneuploidy and reproductive hormones. Reproductive Toxicology 42 232-241. (doi:10.1016/j.reprotox.2013.10.001)

Kholkute SD, Rodriguez J \& Dukelow WR 1994 Effects of polychlorinated biphenyls (PCBs) on in vitro fertilization in the mouse. Reproductive Toxicology 8 69-73. (doi:10.1016/0890-6238(94)90069-8)

Krockova J, Massányi P, Toman R, Danko J \& Roychoudhury S 2012 In vivo and in vitro effect of bendiocarb on rabbit testicular structure and spermatozoa motility. Journal of Environmental Science and Health. Part A, Toxic/Hazardous Substances \& Environmental Engineering 47 1301-1311. (doi:10.1080/10934529.2012.672136)

Lemaire G, Terouanne B, Mauvais P, Michel S \& Rahmani R 2004 Effect of organochlorine pesticides on human androgen receptor activation in vitro. Toxicology and Applied Pharmacology 196 235-246. (doi:10.1016/j.taap.2003.12.011)

Luconi M, Bonaccorsi L, Forti G \& Baldi E 2001 Effects of estrogenic compounds on human spermatozoa: evidence for interaction with a nongenomic receptor for estrogen on human sperm membrane. Molecular and Cellular Endocrinology 178 39-45. (doi:10.1016/ S0303-7207(01)00416-6)

Mably TA, Bjerke DL, Moore RW, Gendron-Fitzpatrick A \& Peterson RE 1992 In utero and lactational exposure of male rats to 2,3,7,8tetrachlorodibenzo-p-dioxin. 3. Effects on spermatogenesis and reproductive capability. Toxicology and Applied Pharmacology 114 118-126. (doi:10.1016/0041-008X(92)90103-Y)

Maravilla-Galván R, Fierro R, González-Márquez H, Gómez-Arroyo S, Jiménez I \& Betancourt M 2009 Effects of atrazine and fenoxaprop-ethyl on capacitation and the acrosomal reaction in boar sperm. International Journal of Toxicology 28 24-32. (doi:10.1177/1091581809333138)

Massart F \& Saggese G 2010 Oestrogenic mycotoxin exposures and precocious pubertal development. International Journal of Andrology 33 369-376. (doi:10.1111/j.1365-2605.2009.01009.x)

Mazur W \& Adlercreutz H 2000 Overview of naturally occurring endocrine-active substances in the human diet in relation to human health. Nutrition 16 654-658. (doi:10.1016/S0899-9007(00)00333-6)

Minervini F, Lacalandra GM, Filannino A, Nicassio M, Visconti A \& Dell'Aquila ME 2010 Effects of in vitro exposure to natural levels of zearalenone and its derivatives on chromatin structure stability in equine spermatozoa. Theriogenology 73 392-403. (doi:10.1016/j.theriogenology.2009.09.023)

Mocarelli P, Gerthoux PM, Patterson DG Jr, Milani S, Limonta G, Bertona M, Signorini S, Tramacere P, Colombo L, Crespi C et al. 2008 Dioxin exposure, from infancy through puberty, produces endocrine disruption and affects human semen quality. Environmental Health Perspectives 116 70-77. (doi:10.1289/ehp.10399)

Mocarelli P, Gerthoux PM, Needham LL, Patterson DG Jr, Limonta G, Falbo R, Signorini S, Bertona M, Crespi C, Sarto C et al. 2011 Perinatal exposure to low doses of dioxin can permanently impair human semen quality. Environmental Health Perspectives 119 713-718. (doi:10.1289/ ehp.1002134)

Mohamed el SA, Park YJ, Song WH, Shin DH, You YA, Ryu BY \& Pang MG 2011 Xenoestrogenic compounds promote capacitation and an acrosome reaction in porcine sperm. Theriogenology 75 1161-1169. (doi:10.1016/j.theriogenology.2010.11.028)

Mota PC, Tavares RS, Cordeiro M, Pereira SP, Publicover SJ, Oliveira PJ \& Ramalho-Santos J 2012 Acute effects of TCDD administration: special emphasis on testicular and sperm mitochondrial function. Asian Pacific Journal of Reproduction 1 269-276. (doi:10.1016/S2305-0500(13) 60091-3)

Mukhopadhyay D, Nandi P, Varghese AC, Gutgutia R, Banerjee S \& Bhattacharyya AK 2010 The in vitro effect of benzo[a]pyrene on human sperm hyperactivation and acrosome reaction. Fertility and Sterility 94 595-598. (doi:10.1016/j.fertnstert.2009.02.031)

Olsen AK, Andreassen A, Singh R, Wiger R, Duale N, Farmer PB \& Brunborg G 2010 Environmental exposure of the mouse germ line: DNA adducts in spermatozoa and formation of de novo mutations during spermatogenesis. PLOS ONE 5 e11349. (doi:10.1371/journal.pone. 0011349)

Pant N, Pant A, Shukla M, Mathur N, Gupta Y \& Saxena D 2011 Environmental and experimental exposure of phthalate esters: the toxicological consequence on human sperm. Human \& Experimental Toxicology 30 507-514. (doi:10.1177/0960327110374205) 
Pant N, Pant AB, Chaturvedi PK, Shukla M, Mathur N, Gupta YK \& Saxena DK 2013 Semen quality of environmentally exposed human population: the toxicological consequence. Environmental Science and Pollution Research International 20 8274-8281. (doi:10.1007/s11356013-1813-8)

Pelkonen O \& Nebert DW 1982 Metabolism of polycyclic aromatic hydrocarbons: etiologic role in carcinogenesis. Pharmacological Reviews $\mathbf{3 4}$ 189-222.

Penning TM 2004 Aldo-keto reductases and formation of polycyclic aromatic hydrocarbon o-quinones. Methods in Enzymology 378 31-67. (doi:10.1016/S0076-6879(04)78003-9)

Pflieger-Bruss S, Hagemann S, Körner W, Hanf V, Köhn F-M, Müller C \& Schill WB 2006a Effects of single non-ortho, mono-ortho, and di-ortho chlorinated biphenyls on human sperm functions in vitro. Reproductive Toxicology 21 280-284. (doi:10.1016/j.reprotox.2005.09.011)

Pflieger-Bruss S, Heitkamp S, Hagemann S, Körner W, Köhn FM, Müller C \& Schill WB 2006b Influence of tris(4-chlorophenyl)methanol, non-ortho PCB 77 and $\gamma$-hexachlorocyclohexane on human sperm function in vitro. Andrologia 38 39-47. (doi:10.1111/j.1439-0272.2006. 00682.x)

Phillips KP \& Tanphaichitr N 2008 Human exposure to endocrine disrupters and semen quality. Journal of Toxicology and Environmental Health. Part B, Critical Reviews 11 188-220. (doi:10.1080/10937400701873472)

Preau JL Jr, Wong LY, Silva MJ, Needham LL \& Calafat AM 2010 Variability over 1 week in the urinary concnetrations of metabolites of diethyl phthalate and di(2-ethylhexyl) phthalate among eight adults: an observational study. Environmental Health Perspectives 118 1748-1754. (doi:10.1289/ehp.1002231)

Rahman MS, Kwon WS, Lee JS, Yoon SJ, Ryu BY \& Pang MG 2015 Bisphenol-A affects male fertility via fertility-related proteins in spermatozoa. Scientific Reports 5 9169. (doi:10.1038/srep09169)

Richard JL 2007 Some major mycotoxins and their mycotoxicoses an overview. International Journal of Food Microbiology 119 3-10. (doi:10.1016/j.ijfoodmicro.2007.07.019)

Roediger B, van der Ven $H$, Schlebusch $H$, Wagner $U$, Knapp $M$, Al-Hasani S, Dietrich K \& Krebs D 1989 Einfluß von Pestiziden auf die Funktion von Spermatozoen in vitro. Archives of Gynecology and Obstetrics 245 1041-1042. (doi:10.1007/BF02417677)

Russo A, Troncoso N, Sanchez F, Garbarino JA \& Vanella A 2006 Propolis protects human spermatozoa from DNA damage caused by benzo[a] pyrene and exogenous reactive oxygen species. Life Sciences $\mathbf{7 8}$ 1401-1406. (doi:10.1016/j.Ifs.2004.10.085)

Safe SH 1994 Polychlorinated biphenyls (PCBs): environmental impact, biochemical and toxic responses, and implications for risk assessment. Critical Reviews in Toxicology 24 87-149. (doi:10.3109/10408449409049308)

Sambuu R, Takagi M, Namula Z, Otoi T, Shiga S, Rodrigues Dos Santos R \& Fink-Gremmels J 2011 Effects of exposure to zearalenone on porcine oocytes and sperm during maturation and fertilization in vitro. Journal of Reproduction and Development 57 547-550. (doi:10.1262/ jrd.11-026H)

Schiffer C, Müller A, Egeberg DL, Alvarez L, Brenker C, Rehfeld A, Frederiksen H, Wäschle B, Kaupp UB, Balbach M et al. 2014 Direct action of endocrine disrupting chemicals on human sperm. EMBO Reports 15 758-765. (doi:10.15252/embr.201438869)

Sengupta P \& Banerjee R 2014 Environmental toxins: alarming impacts of pesticides on male fertility. Human \& Experimental Toxicology 33 1017-1039. (doi:10.1177/0960327113515504)

Silvestroni L \& Palleschi S 1999 Effects of organochlorine xenobiotics on human spermatozoa. Chemosphere 39 1249-1252. (doi:10.1016/ S0045-6535(99)00192-7)

Silvestroni L, Fiorini R \& Palleschi S 1997 Partition of the organochlorine insecticide lindane into the human sperm surface induces membrane depolarization and $\mathrm{Ca}^{2+}$ influx. Biochemical Journal 321 691-698. (doi:10.1042/bj3210691)

Sipinen V, Laubenthal J, Baumgartner A, Cemeli E, Linschooten JO, Godschalk RW, Van Schooten FJ, Anderson D \& Brunborg G 2010 In vitro evaluation of baseline and induced DNA damage in human sperm exposed to benzo[a]pyrene or its metabolite benzo[a]pyrene-7,8diol-9,10-epoxide, using the comet assay. Mutagenesis 25 417-425. (doi:10.1093/mutage/geq024)
Takatori S, Akutsu K, Kondo F, Ishii R, Nakazawa H \& Makino T 2012 $\mathrm{Di}(2$-ethylhexyl)phthalate and mono(2-ethylhexil)phthalate in media for in vitro fertilization. Chemosphere 86 454-459. (doi:10.1016/j.chemosphere.2011.09.043)

Tavares RS, Mansell S, Barratt CL, Wilson SM, Publicover SL \& RamalhoSantos Jp 2013 p'-DDE activates CatSper and compromises human sperm function at environmentally relevant concentrations. Human Reproduction 28 3167-3177. (doi:10.1093/humrep/det372)

Tavares RS, Amaral S, Paiva C, Baptista M \& Ramalho-Santos J 2015 In vitro exposure to the organochlorine $\mathrm{p}, \mathrm{p}^{\prime}-\mathrm{DDE}$ affects functional human sperm parameters. Chemosphere 120C 443-446. (doi:10.1016/j.chemosphere.2014.08.075)

Toppari J, Larsen JC, Christiansen P, Giwercman A, Grandjean P, Guillette LJ Jr, Jégou B, Jensen TK, Jouannet P, Keiding N et al. 1996 Male reproductive health an $\mathrm{d}$ environmental xenoestrogens. Environmental Health Perspectives 104 741-803. (doi:10.1289/ehp. 96104s4741)

Tsakmakidis IA, Lymberopoulos AG, Alexopoulos C, Boscos CM \& Kyriakis SC 2006 In vitro effect of zearalenone and $\alpha$-zearalenol on boar sperm characteristics and acrosome reaction. Reproduction in Domestic Animals 41 394-401. (doi:10.1111/j.1439-0531.2006. 00679.x)

Tsakmakidis IA, Lymberopoulos AG, Khalifa TA, Boscos CM, Saratsi A \& Alexopoulos C 2008 Evaluation of zearalenone and $\alpha$-zearalenol toxicity on boar sperm DNA integrity. Journal of Applied Toxicology 28 681-688. (doi:10.1002/jat.1322)

Tsutsumi $\mathrm{O}$, Uechi $\mathrm{H}$, Sone $\mathrm{H}$, Yonemoto J, Takai $\mathrm{Y}$, Momoeda $\mathrm{M}$, Tohyama C, Hashimoto S, Morita M \& Taketani Y 1998 Presence of dioxins in human follicular fluid: their possible stage-specific action on the development of preimplantation mouse embryos. Biochemical and Biophysical Research Communications 250 498-501. (doi:10.1006/ bbrc.1998.9340)

Van den Berg $M$, Birnbaum LS, Denison $M$, De Vito $M$, Farland $W$, Feeley M, Fiedler H, Hakansson H, Hanberg A, Haws L et al. 2006 World Health Organization reevaluation of human and mammalian toxic equivalency factors for dioxins and dioxin-like compounds. Toxicological Sciences 93 223-241. (doi:10.1093/toxsci/kfl055)

Watanabe S \& Kamiguchi Y 2001 Chromosome analysis of human spermatozoa following in vitro exposure to cyclophosphamide, benzo [a]pyrene and $\mathrm{N}$-nitrosodimethylamine in the presence of rat liver S9. Mutation Research 491 57-63. (doi:10.1016/S1383-5718(00)00170-4)

Xia Y, Zhu P, Han Y, Lu C, Wang S, Gu A, Fu G, Zhao R, Song L \& Wang X 2009 Urinary metabolites of polycyclic aromatic hydrocarbons in relation to idiopathic male infertility. Human Reproduction $\mathbf{2 4}$ 1064-1074. (doi:10.1093/humrep/dep006)

Younglai EV, Foster WG, Hughes EG, Trim K \& Jarrell JF 2002 Levels of environmental contaminants in human follicular fluid, serum, and seminal plasma of couples undergoing in vitro fertilization. Archives of Environmental Contamination and Toxicology 43 121-126. (doi:10.1007/s00244-001-0048-8)

Yuan C, Wang C, Gao SQ, Kong TT, Chen L, Li XF, Song L \& Wang YB 2010 Effects of permethrin, cypermethrin and 3-phenoxybenzoic acid on rat sperm motility in vitro evaluated with computer-assisted sperm analysis. Toxicology In Vitro 24 382-386. (doi:10.1016/j.tiv.2009.11.001)

Yurdakok B, Tekin K, Daskin A \& Filazi A 2015 Effects of polychlorinated biphenyls 28, 30 and 118 on bovine spermatozoa in vitro. Reproduction in Domestic Animals 50 41-47. (doi:10.1111/rda.12447)

Zinedine A, Soriano JM, Molto JC \& Manes J 2007 Review on the toxicity, occurrence, metabolism, detoxification, regulations and intake of zearalenone: an oestrogenic mycotoxin. Food and Chemical Toxicology 45 1-18. (doi:10.1016/j.fct.2006.07.030)

Received 5 August 2015

First decision 8 September 2015

Revised manuscript received 6 October 2015

Accepted 12 October 2015 